\title{
Educational Level and Tax Compliance: Empirical Evidence From Nigeria
}

\author{
Dr. Stanley Ogoun \\ Department of Accounting, Faculty of Management Sciences, Niger Delta University, \\ Wilberforce Island, Bayelsa State, Nigeria \\ Godspower Anthony Ekpulu (Corresponding author) \\ Department of Accounting, Faculty of Management Sciences, Niger Delta University \\ Wilberforce Island, P.M.B.071, Yenagoa, Bayelsa State, Nigeria \\ E-mail: godspower.ekpulu@mail.ndu.edu.ng
}

Received: December 23, 2019 Accepted: January 29, $2020 \quad$ Published: March 12, 2020

doi:10.5296/ijafr.v10i1.16106

URL: https://doi.org/10.5296/ijafr.v10i1.16106

\begin{abstract}
The study interrogates the relationship between educational level and tax compliance in Nigeria. The study employs the ex post facto research design to ascertain how government investment in education enhances tax compliance. The study covers 17 years (2002-2018) for both tax revenue (a surrogate for tax compliance) and education expenditure (a surrogate for educational level). From the empirical results, the study concludes that there is a positive nexus between government expenditure on education and tax revenue. The study, therefore, recommends that as a matter of necessity, the government should invest more in the overall educational demand of her citizens not only from tax revenues but from other oil and non-oil sources. The governments, from the federal and state levels, should act as a matter national priority endeavour to meet up with the international budgetary benchmark allocation for education, as recommended by the United Nations Educational, Scientific and Cultural Organization (UNESCO) in its Education for All (EFA) document 2000-2015. This will give Nigerians more access to quality education that would result in moving up the global ranking in HDI with its resultant benefits.
\end{abstract}

Keywords: Education, Tax compliance, Human development index 


\section{Introduction}

Empirical studies in the field of behavioural sciences have documented clearly the impact of various situational, socio-cultural and demographic factors that, not only stimulates but also influences human behaviour. No wonder, a proper understanding of demographic factors are considered critical in apprehending consumer behaviour, market planning for a successful product offering, as well as, gaining competitive advantage. The centrality of demographics is well captured in the literature of marketing, as it constitutes a major field of study in the marketing domain. However, its place in the accounting discipline seems to be non-existent. As a result, accounting planners often get enamoured with the number game, without factoring in the dynamics of demographics in accounting policy implementation in most domains. One critical area where this neglect is very obvious is in the field of tax administration.

Whereas, the number of children or dependants as the case may be, is considered through some form of tax allowances, repeal by the Consolidated Relief Allowance (CRA), was seen to be the demographic consideration that could influence tax compliance. However, the broad influence of demographics in the behavioural disposition of individuals towards their tax liability is often ignored, except for the punitive or sanction instrument that is dangled on the head of non-complaints'.

As a nation, several efforts have been made to widen the tax net, but as to whether these efforts have culminated in the attainment of the desired results is yet to be empirically determined. Given the unequivocal fact of the existence of various determinants of behavioural disposition, coupled with the age-long anti taxation mindset of most humans, especially in high poverty-stricken and developing countries, it becomes not only imperative to isolate and interrogate the weight of each demographic dimension and how it relates to citizens' behavioural disposition towards taxation.

Further, as observed by Ogoun (2014), taxation as tool for public revenue generation was systematically and methodically confined to the background in Nigeria for decades, as a result of the massive inflow of public revenue, occasioned by not only the discovery of crude oil in commercial quantity but also the resultant boom in the international market for crude oil. With this confinement, tax authorities exploited the system purely for their benefit resulting in a poignant and very negative attitude by citizens towards taxation. A further dimension that propels this negative attitude is the perceived lack of accountability and good governance by the citizenry. Thus, as Nigeria grapples with the various reform efforts tailored at re-jigging taxation as the primary instrument for generating public revenue on account of, not only the glut in the international market for crude oil but also the stochastic nature of the market, coupled with the movement towards renewable energy sources, it becomes inevitable to interrogate the effect of demographic stimulants on citizens' tax behavioural disposition.

Furthermore, from empirical and conceptual studies conducted, many factors had been attributed to tax compliance and non-compliance within and outside Nigeria. Demographic variables and the level of tax awareness have topped most tax compliance researches with 
mixed findings. From the demographic variables, general education level with tax compliance had received very little attention, and most of the studies on educational level and tax compliance were conducted outside the Nigerian context. Bobek, Roberts and Sweeney (2007) posit that low educational level may yield low tax compliance. However, contrary to their submission, Eva, Martin, Christine and Erich (2017) in their study, concludes that people with higher education relates to low tax evasion but higher tendencies of tax avoidance.

Also, the extant literature has well-documented studies that have demonstrated the role education plays in modelling and shaping behaviour. This no doubt informs the consideration of education for all as one of the cardinal objectives of the United Nation's Millennium Development Goals (MDGs) and now Sustainable Development Goals (SDGs). Given also that Nigeria ranks very low in the human development index, predicated on her low level of investment in education, healthcare and basic infrastructure, re-jigging taxation to make it the primary source of generating public revenue must be contextualized within the framework of the country's educational index. Against these backdrops, this study empirically interrogates the relationship between educational level and tax compliance for a period of 17 years (2002-2018.

\section{Literature Review}

\subsection{The Education Construct}

The level of educational attainment according to the Organisation of Economic Cooperation and Development [OECD] (2003) is the highest grade completed by an individual within the most advanced level attended in a country's educational system where the education was obtained. Educational attainment can be referred to as the highest level of education that a person has completed. It can also be explained to be the highest level of knowledge acquisition within a particular discipline obtained by an individual in line with the educational system of the country. However, the term Education, according to Fafunwa (1974), is what each generation renders to its younger ones that enable them to develop the required skills, ability, attitude and other behavioural attributes which are relevant to the growth of the society where they domicile. Uwadia (cited in Ugbogbo, Akwemoh \& Omoregie 2013) posits that Education in a broad sense is a means by which a person attains the many physical and social capabilities required by the society in which he/she is born into to function. According to Uwadia, education to a nation is just like the mind is to the body, just as a diseased mind is handicapped in the coordination and direction of the bodily activities. According to Eduwen (cited in Ugbogbo, Akwemoh \& Omoregie, 2013), Education is the process of acquisition of knowledge; that is, it involves the teaching and learning process. Thus, the educational system is one of the most important social - control tools that foster national development.

Generally, education is the instrument used for the advancement of human beings in their cognitive, affective, psychomotor and psycho productive domains which is achieved through the learning and teaching process. Nevertheless, education has been found to have a different 
relationship with tax compliance. Despite having positive associations, negative correlations were also stated between education and the level of tax compliance that can be credited to utilising opportunities for tax avoidance \& evasion with increasing fiscal knowledge (Helhel \& Ahmed, 2014).

\subsection{Tax Compliance}

The explanation of tax compliance is generally evaluated in line with tax laws, that is, concerning the extent to which taxpayers submit to tax law. The level of non-compliance may be measured by way of the tax gap, that is, the variance between the actual revenue collected and the amount that would be collected if there were compliance to a maximum rate of 100 per cent (Ekpulu, Iyoha \& Bingilar, 2016). Kirchler (2007) perceived a more straightforward definition in which tax compliance is defined as the most neutral term to describe taxpayers' willingness to pay their taxes. Abdul-Jabbar (2009) further described tax compliance to suggest adherence to tax reporting requirements; that is, that the taxpayer files all required tax returns at the proper time and that the returns accurately report tax liability under the tax laws, regulations and court decisions applicable at the time the return is filed. An alternative definition has been put forward by James and Alley (1999) earlier on, who considers tax compliance in terms of the tax gap. The tax gap is explained to be the difference between 'true' individual income tax liability and that which is finally collected voluntarily or by enforcement action. Thus, they see non-compliance as failure to fulfil tax reporting requirements, which in other words means that tax compliance is the level of fulfilling tax reporting requirements. Accordingly, tax compliance in this current study depicts the degree to which citizens fulfil their civic responsibility.

\subsection{Theoretical Foundation and Tax Compliance Models}

The existing literature recognizes the existence of theoretical rationale (explaining the taxpayer's compliance attitude, that is, the reasons why taxpayers comply or do not comply) behind the various tax behavioural dispositions of individuals. Two broad approaches have been identified by researchers in explaining compliance or non-compliance behaviour, namely: Economic Deterrence Model and Fiscal Psychology Model.

\subsubsection{Economic Deterrence Models}

Allingham and Sandmo were the first to employ this model in the context of tax compliance study in 1972. The model is based on expected utility theory and deterrence theory. The view from the expected utility theory holds that taxpayers as perfectly amoral utility maximisers, who choose to evade taxes whenever the expected gain exceeds the cost of evasion (Allingham \& Sandmo, 1972). The deterrence theory is more associated with the effects of sanctions and sanction threats, where a rise in the severity of penalties and the certainty of their imposition will discourage undesirable behaviour. Their theoretical analysis suggests that punishment using robust sanctions determined taxpayer compliance behaviour and that an increase in the penalty rate and a higher probability of detection would result in lower non-compliance. 


\subsubsection{Fiscal Psychology (Behavioural) Model}

The behavioural perspective is a composition of sociological and psychological factors, such as age, gender, ethnicity, education, culture, institutional influence, peer influence, ethics and tax morale, as factors that may affect taxpayer compliance behaviour (Helhel \& Ahmed, 2014). This model is significant as it predicts that demographic variables indirectly influence tax compliance behaviour through their effects on non-compliance opportunities and attitudes.

A review of the existing literature on factors affecting individual tax compliance behaviour uncovered three main categories of determinants of such behaviour. These categories according to Richardson (2006) include demographic, economic and behavioural determinants. Demographic determinants include age, gender, education and occupation, while economic determinants include income level, income source, tax rates and sanctions. Behavioural determinants include complexity, fairness, revenue authority contact, peer influence and ethics.

\subsubsection{Theory of Planned Behaviour}

The Theory of Planned Behaviour (TPB) as introduced by Ajzen (1985) in an extension study on the Theory of Reasoned Action (TRA) model. The TPB holds that three determinants influence the intention to accomplish a behaviour and actual human behaviour. These include attitude towards behaviour, the subjective norms, and perceived behavioural control. The TPB model further highlights that behavioural intention is the intermediating variable between attitudes toward behaviour, the subjective norms and perceived behavioural control on the one hand and behaviour on the other (Kirchler, 2007). That is, attitudes toward behaviour correlate with intention and behaviour. If an individual has a positive attitude towards a particular behaviour, it is more likely that the behaviour will result in a highly valued outcome (Kircher, 2007). Interestingly, empirical evidence confirms that attitude towards tax compliance is a vital factor that motivates the taxpayers to respond favourably to the tax laws and influence reported tax compliance behaviour (Chan, Troutman \& O'Bryan, 2000; Bobek \& Hartfiled, 2003; Saad, 2011).

From the TPB, and in line with the study objective, taxpayers behave either positively or negatively to tax laws based on the education they have regarding the tax laws that could earn then some benefits of high avoidance. Also, highly educated taxpayers being equipped with information regarding the self-interest, taxation policies and public expenditure by the government could have an unfavourable tax compliance behaviour. This could suggest that the attitude of taxpayers to comply with the tax laws is a function of their perceived behavioural control and subjective norms towards the government.

\subsubsection{Public Choice Theory}

It emerged in the fifties and gained widespread public attention in 1986, when James Buchanan, one of its two leading architects and Gordon Tullock from George Mason University published The Calculus of Consent in 1962 and was awarded the Nobel Prize in 
economics (Shughart, 2019). According to Shaw (n.d) in the concise encyclopaedia of economics, explain Public Choice Theory as a branch of economics that developed from the study of taxation and public spending. In other words, it can be said to be the economic theory that studies the effectiveness of government (public) spending and taxation and the behaviour of politicians and legislators. In advancing this view, Shughart (2019) maintains that utility maximisation and the overall personal well-being of individuals is a driver of individual behaviour, pointing from the economic model of rational behaviour. However, public choice, like the economic model of rational behaviour on which it is based, according to Shughart, assumes that people are guided primarily by their self-interests and, more important, those in the political process have no different motivation form those in the steak and car market.

In Nigeria, taxpayers see the public choice of government in spending as a self-interest activity without much consideration for the more substantial public interest. Therefore, this study is anchored on the Fiscal Psychology (Behavioural) Model, Theory of Planned Behaviour and Public Choice Theory

\subsection{Human Development Index (HDI) in Nigeria}

The HDI gives a summary measure for assessing long-term progress basically in three dimensions of human development: a long and healthy life, access to education or knowledge and a good standard of living (UNDP, 2018). Life expectancy is a measure for a long and healthy life. Whereas, Knowledge level is measured by mean years of education among the adult population, which depict the average number of years of education Nigerians received in a lifetime by those within the age of 25 years and older; and children of school-entry age gaining access to learning and knowledge by expected years of schooling, which indicate the total number of years of schooling a child of school-entry age can anticipate to receive if prevailing patterns of age-specific admission rates stay the same throughout the child's life. Standard of living is measured by Gross National Income (GNI) per capita.

Statistics show that while no African country is in the "very high human development" rank, six African countries now occupy the "high human development" group (Vanguard, 2018). The countries are known to be the small island nations of Seychelles, 0.797 (62), Mauritius, 0.790 (65), Algeria having 0.754(85), Botswana, 0.717 (101), Libya, 0.706 (108) and even Gabon, with 0.702 (110). The surprising entry is Libya, despite the level of devastating wars experienced in the country. Fourteen countries in the region are now in the "medium human development" group. They include South Africa, 113 (0.699), Egypt, 115 (0.696), Morocco, 123 (0.667), Cape Verde, 125 (0.654), Namibia, 129 (0.647), Congo, 137 (0.606).

Sadly, Nigeria, with a population of over 200 million according to World Population Review (WPR, 2019) is rank with countries with low HDI and Least Developed Countries (LDC). Countries in this HDI categories are categorised within 0.55 below. LDCs are countries faced with widespread poverty, unstable governments, lack of access to good healthcare, and poor education. Moreover, the income level and life expectancies of these countries are low coupled with high birth rates (WPR, 2019). According to UNDP (2018) among 188 countries 
in 2016 HDI indices, Nigeria is ranked 156, while as at 2018 HDI indices and statistical update, Nigeria is ranked among those countries with low HDI scoring 0.532 even below 0.55 in a scale of 1.0 .

The above ranking shows how grossly deficient Nigeria is when it comes to investment in human development. In one way or the other, there are possibilities that the low investment level in human development might have affected the way the citizens behave or respond to government policies, mostly in the areas of taxation. As a rational thinker, the human will mostly respond favourably to government tax policies when they feel that there is the utilisation of tax revenues for the public good and not for self-interest.

\subsection{Hypothesis Development}

There is an existing opinion that empirical results are unclear regarding the relationship between educational level and tax compliance. Those with higher education tend to have a better knowledge of the complexity of tax laws and the embedded technical terms and abstractions. Consequently, people that are more educated understand the law and filing rules. While, the less educated people with little understanding are likely to encounter an error, mistakes when filing their taxes (McKerchar, 2001; Wong \& Lo, 2015; Hofmann, Voracek, Bock \& Kirchler, 2017). Also, Higher education is related to access to information that provides insight into tax avoidance schemes. Therefore, higher education may be related to lower evasion but higher avoidance tendencies. Corroborating the above assertion, Eva, Martin, Christine and Erich (2017), in their empirical study, conclude that people with higher education relates to low tax evasion, but higher tendencies of tax avoidance. Technically, prior finding by Kirchler (2007) is in tandem with Eva et al. (2017). Kirchler finding reveals that high tax complexity, thus, limits the understanding of one's tax duties and high insecurity, fuel compliance. This suggests that those with low education in understanding tax complexity tend to comply more with tax policies.

Contrary views maintain that a positive correlation exists between education and tax compliance. For instance, the empirical study by Jeyapalan, Norhani and Noor (2003) evaluates how education influence tax compliance among undergraduate students in Malaysia. The statistical findings confirm the existence of a correlation between education and tax compliance. The correlation shows a general consistency, mainly to general avoidance and personal avoidance related question. There is an improvement in personal tax compliance among students, especially among females after one semester of pursuing an introductory taxation course.

In a similar study, Wong and Lo (2015) conducted a survey study on students offering taxation course. The study focused on analysing any changes in students' responses to two specific tax compliance situations. Findings from the study reveal that there is a significant improvement in sales tax and income tax compliance among undergraduate students and postgraduate students if they had been subjected to gain exposure on general tax education (Undergraduate level) and technical tax course (Postgraduate level). Their findings reveal no significant association between technical tax education and undergraduate students' tax 
compliance. Overall, these findings suggest that, at both the undergraduate and postgraduate level, general tax education and technical tax education are useful for improving the level of tax compliance for both students. From their conclusion, it is evident that both the contents of a tax course and educational levels of a program are essential factors which affect the effectiveness of changing students' tax compliance behaviour via education. These findings give a double-edge disclosure that education does not only facilitate tax compliance but also, through the knowledge of taxation courses taken, improves tax compliance.

Chan et al. (2000) in their survey study compared Hong Kong and US taxpayers' compliance behaviour. Their finding reveals that the US respondents' decisions to obey tax laws were driven mainly by education and their age, which in turn positively influenced moral development and attitude. Also, Torgler, Demir, Macintyre and Schaffner (2008) and Torgler (2012) who investigate the relationship between the level of education and tax compliance, found that taxpayers that are more educated tend to be more compliant than taxpayers who have no formal education. In a similar finding, Bobek, Roberts, and Sweeney, (2007) conclude that low educational level may relate to less tax compliance.

Furthermore, extant studies on tax compliance outside the Nigerian jurisdiction generally finds that education levels are positively associated with tax compliance. For instance, Mathieu, Price and Antwi (2010) and Muehlbacher, Kirchler \& Schwarzenberger (2011) finds that voluntary tax compliance is positively associated with education. These two studies use taxpayers' overall education level to measure the influence of education on tax compliance.

Eiya, Ilaboya and Okoye (2016) examine the influence of religiosity on tax compliance in Nigeria. In order to obtain the opinion of taxpayers about tax compliance, their study employed a cross-sectional survey research design. Findings from the survey show that the collective strength of religiosity and education have a significant influence on tax compliance with a p-value of 0.00 which was less than the critical t-value at $5 \%$ level, whereas, on the regression analysis further observation shows that religiosity alone has no significant relationship with tax compliance but the interaction of religiosity and education, religiosity and income had a significant influence on tax compliance in Nigeria.

As observed from the review of related and relevant literature, an educated taxpayer with knowledge of the complexity in taxation may show a poor attitude to tax compliance. His or her perceived behaviour towards the sharing and utilisation of tax revenue by the governments which is mostly adjudged to be very poor when it comes to the provision of public good in Nigeria can create unfavourable tax compliance.

For instance, Olowookere \& Fasina (2013), examined the impact of tax education programme on tax payment compliance behaviour in Lagos state Nigeria. The study employed the quasi-experimental research design for the survey and the simple random sampling technique to enlist 250 Taxpayers in Lagos State. The Analysis of Variance (ANOVA) employed for the test of hypotheses revealed that tax education programme has a significant influence on taxpayers' voluntary compliance in Lagos State, Nigeria. Also, Imam, Sugeng and Yuli (2014), investigated the factors that may affect tax compliance from SME entrepreneurs. The 
study applied qualitative and quantitative approaches to the method of data analysis. The unit of analysis is focused on SME entrepreneurs of handicraft field districts/cities in East Java. The study's output indicates that tax compliance can be built through tax fairness, formed through the life of the entrepreneurs themselves in understanding the tax system and terms of the tax rate, tax penalties, tax administration, and tax type amongst others. The study concludes that SME entrepreneurs can understand their tax obligations when there is an aspect of fairness and tax benefits. The study posits that there is a need for tax educational activities through the dissemination of taxation and tax benefits, in order to sustain and advance the operations of SMEs entrepreneurs in East Java, Indonesia. On their part, Oladipupo and Obazee (2016) investigated how taxpayers' knowledge and penalties, influence tax compliance amongst small and medium enterprises in Nigeria, using a survey research design. Their findings show that tax knowledge had a significant positive impact on tax compliance, while there is also a positive and insignificant impact between tax penalty and tax compliance. Thus, the study deposes that tax knowledge has a higher tendency to promote tax compliance than the tax penalty.

In addition, Wadesango and Mwandambira (2018), evaluated if lack of tax knowledge contributed to high levels of tax non-compliance amongst SMEs in Zimbabwe. The study employed a quantitative research approach for a sample of 35 SMEs and 40 tax officials. The findings reveal that SMEs in Zimbabwe have good knowledge about taxation, but lack a more in-depth understanding like the difference between presumptive taxation and income-based taxation. Nevertheless, the study avers that this has no significant influence on their non-compliance behaviour. It also reveals that in order for tax knowledge to influence tax compliance positively, the issue of tax rates and corruption should be addressed. The study recommends that tax authorities in Zimbabwe should continue to raise tax awareness and taxpayer education. In the same vein, Gotora and Samuel (2018) examined the influence of taxpayer education on voluntary tax compliance in Tanzania, with specific reference on print and electronic media taxpayer education programmes on tax compliance. The study findings established that education through print and electronic media taxpayer education programmes, website-based taxpayer education, and tax stakeholders' workshops impacts on the level of voluntary tax compliance in Tanzania.

The empirical literature thus reveals the focus of prior studies on various aspects of tax education. The empirical studies did focus on the taxpayer's education, knowledge and awareness concerning tax compliance, leaving gaps for further dimensional research efforts. The gap which this study sought to close is to relate government spending on the general level of citizens' education, and how this translates to improved citizenship behaviour via tax compliance. This is because it is widely accepted that general education leads to improved standards of leaving via better awareness and knowledge. Probably, this accounts for it being one of the major planks of erstwhile United Nations Millenium Development Goals (MDGs).

Meanwhile, as to whether improvement in the general level of education translates to better tax compliance have not received general consensus. Prior studies in other climes as earlier capture in this study have shown conflict strands. Hence, this study tries to fill this lacuna in 
the literature, via reliance on Nigerian government expenditure on education, in line with our study objective. This is the premise for the stated hypothesis:

Ho1: Tax compliance rate is significantly not dependent on educational level

\section{Methodology}

This study employs the ex post facto research design to ascertain how government investment in education enhances tax compliance in Nigeria. The study covers a period of 17 years (2002-2018) for both tax revenue (a surrogate for tax compliance) and education expenditure (a surrogate for educational level). From the conceptual review of tax compliance, it is clear that tax compliance is the portion of tax revenue collected. The justification for using education expenditure as a surrogate was centred on the view that as the government spend more on the education of her citizens, it is expected that it will translate to better and higher educational level for Nigerians. Secondary data was extracted from the Central Bank of Nigeria (CBN) Statistical Bulletin, and the Federal Inland Revenue Service (FIRS) online published information. The data was collected and analysed using Ordinary Least Square technique and Spearman rank-order Covariance analysis.

Further diagnostic tests were conducted to check the viability and significance of the model. From the model below, the study uses tax revenue as a surrogate for tax compliance, and education expenditure as a surrogate for educational level. From the conceptual review of tax compliance above, it is clear that tax compliance is portrayed by the portion of tax revenue collected. The justification for using education expenditure as a proxy was centred on the view that as the government spend more on the educational yearnings of her citizens, it is expected that it will translate to higher education level for Nigerians.

\subsection{Model Specifications and Estimation}

$\mathrm{TAXR}=f(\mathrm{EDUE})$

\section{LOGTAXRt $=\beta 0+\beta 1$ LOGEDUEt $+\mu \mathrm{t}$}

A priori expectation: $\beta 0>0, \beta 1>0$,

Where:

LOGTAXR $=$ Log of Tax Revenue

LOGEDUE $=$ Log of Education Expenditure

$\beta 0=$ Constance/intercept

$\beta 1=$ Beta coefficients

$\mu=$ Stochastic error term/disturbance 


\section{Analysis and Observation}

\subsection{Regression Result}

Dependent Variable: LOGTAXR

Method: Least Squares

Date: $11 / 15 / 19 \quad$ Time: $13: 56$

Sample: 20022018

Included observations: 17

\begin{tabular}{lllll}
\hline Variable & \multicolumn{1}{l}{ Coefficient Std. Error } & t-Statistic & Prob. \\
\hline C & 2.765946 & 0.621571 & 4.449927 & 0.0005 \\
\hline LOGEDUE & 0.960405 & 0.117148 & 8.198245 & 0.0000 \\
\hline R-squared & 0.817543 & Mean dependent var & 7.822319 \\
\hline Adjusted R-squared & 0.805379 & S.D. dependent var & 0.721195 \\
\hline S.E. of regression & 0.318161 & Akaike info criterion & 0.657614 \\
\hline Sum squared resid & 1.518398 & Schwarz criterion & 0.755639 \\
\hline Log likelihood & -3.589718 & Hannan-Quinn criter. & 0.667358 \\
\hline F-statistic & 67.21123 & Durbin-Watson stat & 0.761796 \\
\hline Prob(F-statistic) & 0.000001 & & \\
\hline
\end{tabular}

Source: E views output 2019

From the above regression output, the coefficient of the log of education expenditure (LOGEDUE) is 0.960405 and a probability value of $(0.0000)$ which is less than $5 \%(<0.05)$ significant level, meaning that the coefficient is strongly significant in determining the value of the dependent variable; log of tax revenue (LOGTAXR). The value of the beta coefficient further suggests that a percentage change in educational expenditure will cause tax revenue to increase by $0.96 \%$. This holds that if Nigeria government increase her budget on education by 1 per cent, there will be a 0.96 per cent increase in tax revenue. There will be a high level of 
tax compliance because the citizens will be happy that the government is utilising the revenue from taxes on human development which is one of the major cornerstones to a nation's development.

Further, the R-squared with a value of 0.8175 indicates that about $81 \%$ variation in TAXR is accounted for or predicted by the amount of government expenditure (EDUE) on education. This gives a very high confidence level $(81 \%)$ that educational expenditure correlates with tax revenue. Also, at 1\% significant level, we can conclude that the EDUE significantly affect TAXR having a Prob. value of (0.000001).

\subsection{Covariance Analysis}

Covariance Analysis: Spearman rank-order

Date: 11/15/19 Time: 07:26

Sample: 20022018

Included observations: 17

Correlation

\begin{tabular}{lll}
\hline Probability & EDUE & TAXR \\
\hline
\end{tabular}

EDUE $\quad 1.000000$

\begin{tabular}{lll}
\hline TAXR & 0.946078 & 1.000000 \\
\hline 0.0000 & -----
\end{tabular}

Source: E views output 2019

From the spearman rank-order covariance analysis, the null hypothesis states that there is no correlation between Tax revenue and Education expenditure. However, from the output, the correlation between TAXR and EDUE (0.946078) tend towards (1) one, indicating a positive and robust relationship between the variables, hence the null hypothesis of no correlation was rejected. It also shows that the relationship is significant having a Prob. value less than 5 per cent (0.000).

From the result, we can conclude that when the Nigerian Government increases spending on education, either capital or human development, there is the certainty that tax compliance level will appreciate. Moreover, the theory of Fiscal Psychology (Behavioural) Model, 
Theory of Planned Behaviour and Public Choice Theory in no small extent influence the tax compliance level of individuals. This may be true because human perception about government expenditure affects how they may behave or react to government policies. When the Nigerian government invest some of the enormous revenue from taxes on education, it will increase the educational level of Nigerians, and there will be further positive behaviour from Nigerians toward government policies, more especially, government tax policies.

\subsection{Test for Stationarity}

Unit root test

Null Hypothesis: D(LAGTAXR) has a unit root

Exogenous: Constant

Lag Length: 0 (Automatic - based on SIC, maxlag=2)

\begin{tabular}{|c|c|c|c|}
\hline & & t-Statistic & Prob.* \\
\hline Augmented Dickey & Fuller test statistic & -3.228408 & 0.0399 \\
\hline \multirow[t]{3}{*}{ Test critical values: } & $1 \%$ level & -4.004425 & \\
\hline & $5 \%$ level & -3.098896 & \\
\hline & $10 \%$ level & -2.690439 & \\
\hline
\end{tabular}

Augmented Dickey-Fuller Test Equation

Dependent Variable: D(LAGTAXR,2)

Method: Least Squares

Date: $11 / 15 / 19$ Time: 08:49

Sample (adjusted): 20052018

Included observations: 14 after adjustments

\begin{tabular}{lllll}
\hline Variable & \multicolumn{2}{l}{ Coefficient Std. Error } & t-Statistic & Prob. \\
\hline D(LAGTAXR(-1)) & -0.947338 & 0.293438 & -3.228408 & 0.0072 \\
\hline C & 226.6792 & 213.8634 & 1.059926 & 0.3100 \\
\hline
\end{tabular}

Source: E views output 2019 
The time series model shows that the data is stationary, having a Prob. value of (0.0399) which is less than the $5 \%$ level of significance, hence the null hypothesis of the presence of unit root is rejected. The absolute value of the ADF $t$-statistic in comparison with the $1 \%$ and $5 \%$ level of the critical value also justified the absent of unit root. The above unit root test further confirms the model to be viable as the slope coefficient of the dependent variable (Lag of Tax revenue at 1 st difference) shows a negative coefficient (-0.9473).

\subsection{Serial Correlation Test}

The null hypothesis: There is no serial correlation

Breusch-Godfrey Serial Correlation LM Test:

\begin{tabular}{llll} 
F-statistic & 1.153722 & Prob. F(2,11) & 0.3509 \\
\hline Obs*R-squared & 2.774319 & Prob. Chi-Square(2) & 0.2498
\end{tabular}

Source: E views output 2019

When the Prob. Chi-square of the Observed R-squared is less than 5\% then there is a serial correlation; hence the null hypothesis will be rejected, but when greater than $5 \%$ the null will be accepted. From the diagnostic test, Prob. Chi-Square $(0.2498)$ is higher than 5\%. This suggests that no serial correlation exists among the variables thereby permitting the acceptance of the null hypothesis.

\section{Conclusion, Implications, Recommendation and Contribution}

From the empirical results, the study concludes that there is a positive nexus between government expenditure on education and tax revenue. This suggests that tax compliance, surrogated by tax revenue, is accorded positive response when the government keep increasing her budgetary allocation on education. This implies that the level of tax compliance is a function of how government utilises the tax revenue on education, either on physical and infrastructural development of educational institutions or on human capital development. The implication is that a more educated population will result in a higher tax yield, given that education enhances the cognition of the individual and enhance his behavioural disposition. For a developing country like Nigeria whose economy is crude oil dependent to navigate her way towards deploying taxation as a primary source of revenue would necessarily require citizens buy-in by way of massive investment in human development to which education counts. This conclusion aligns with the views of Mathieu, Price and Antwi (2010) and Muehlbacher, Kirchler \& Schwarzenberger (2011).

The study, therefore, recommends that as a matter of necessity, the government should invest more in the overall educational demand of her citizens not only from tax revenues but from other oil and non-oil sources. The governments, both at the federal and state levels should as a matter national priority endeavour to meet up with the international budgetary benchmark 
allocation for education, as recommended by the United Nations Educational, Scientific and Cultural Organization (UNESCO) in its Education for All (EFA) document 2000-2015. This will give Nigerians more access to and quality education that would result in moving up the global ranking in HDI with its resultant benefits. This will further shape the citizens' attitude towards government policies more especially, tax policies.

Relating general spending on education to citizens' tax compliance using Nigerian country-level data adds to the stock of knowledge it denotes an incursion into tax compliance research from a novel direction. The outcome of this study if deployed by the government would contribute immensely towards improving the current low ranking of Nigeria in the global human development index, as improved funding for general education will ultimately lead to more positive behaviour with implications for the overall polity.

\section{References}

Abdul-Jabbar, H. (2009). Income tax non-compliance of small and medium enterprises in Malaysia: Determinants and tax compliance costs. Doctoral thesis, Curtin University of Technology, Perth, Australia. Retrieved from https://espace.curtin.edu.au/handle/20.500.11937/2115

Ajzen, I. (1985). From intentions to action: A theory of planned behaviour. In J. Kuhl \& J. Beckmam (Eds.), Action Control: From Cognition to Behavior. NY: Springer Verlag.

Allingham, M. G., \& Sandmo, A. (1972). Income tax evasion: A theoretical analysis. Journal of Public Economics, 1(3-4), 323-338.

Bobek, D. D., Roberts, R. W., \& Sweeney, J. T. (2007). The social norms of tax compliance: Evidence from Australia, Singapore, and the United States. Journal of Business Ethics, 74, 49-64. http://doi.org/10.2307/25075443

Bobek, D., \& Hartfiled, C. (2003). An investigation into the theory of planned behavior and the role of moral obligation in tax compliance. Behavioural Research in Accounting, 15(1), 13-38.

Chan, C. W., Troutman, C. S., \& O'Bryan, D. (2000). An expanded model of taxpayer compliance: Empirical evidence from the United States and Hong Kong. Journal of International Accounting Auditing and Taxation, 9(2), 83-103.

Eiya, O., Ilaboya, O. J., \& Okoye, A. F. (2016). Religiosity and tax compliance: Empirical evidence from Nigeria. Igbinedion University Journal of Accounting, 1(1), 27-41.

Ekpulu, G. A., Iyoha, A. I., \& Bingilar, P. F. (2016). Economic and behavioural factors and tax compliance: A conceptual review. Uniben Journal of Accounting, 2(1), 16-28.

Eva, H., Martin, V., Christine, B., \& Erich, K. (2017). Tax compliance across sociodemographic categories: Metaanalyses of survey studies in 111 countries. Journal of Economic Psychology, 62, 63-71. 
Fafunwa, A. B. (1974). History of education in Nigeria. Ibadan: NPS Educational Publishers Ltd.

Gotora, P., \& Samuel, O. M. (2018). The influence of tax payer education on voluntary tax compliance in Tanzania a case study of Monduli district office. International Journal of Management and Commerce Innovations, 6(1), 341-346.

Helhel, Y., \& Ahmed, Y. (2014). Factors affecting tax attitudes and tax compliance: A survey study in Yemen. European Journal of Business and Management, 6(22), 48-58.

Hofmann, E., Voracek, M., Bock, C., \& Kirchler, E. (2017). Tax compliance across sociodemographic categories: Meta-analyses of survey studies in 111 countries. Journal of Economic Psychology, 62, 63-71. http://doi.org/10.1016/j.joep.2017.06.005

Human Development Index (HDI) by Country Population. (2019, October 31). Retrieved from

http://worldpopulationreview.com/countries/human-development-index-(hdi)-by-country/

Imam, K., Sugeng, H. U., \& Yuli, S. (2014). Increasing tax compliance through strengthening capacity of education sector for export oriented SMES handicraft field in East Java Indonesia. European Scientific Journal, 10(7), 170-184.

Jeyapalan, K., Norhani, A., \& Noor, A. (2003). The influence of education on tax avoidance and tax evasion. eJournal of Tax Research, 1(2), 134-146.

Kirchler, E. (2007). The economic psychology of tax behaviour. New York, US: Cambridge University Press.

Mathieu, L., Price, C. W., \& Antwi, F. (2010). The distribution of UK personal income tax compliance costs. Applied Economics, 42(3), 351- 368.

McKerchar, M. (2001). The study of income tax complexity and unintentional noncompliance: Research method and preliminary findings. ATAX Discussion Paper 6. University of Sydney; Orange, Australia. Retrieved October 17, 2019, from https://ssrn.com/abstract=623627

Muehlbacher, S., Kirchler, E., \& Schwarzenberger, H. (2011). Voluntary versus enforced tax compliance: Empirical evidence for the "slippery slope" framework. European Journal of Law and Economics, 32(1), 89-97.

Ogoun, S. (2014). Effective tax administration and institutionalization of accounting systems in small and medium scale enterprises: Evidence from Nigeria. Journal of Social and Management Sciences, 1(2),85-97.

Oladipupo, A. O., \& Obazee, U. (2016). Tax knowledge, penalties and tax compliance in small and medium scale enterprises in Nigeria. iBusiness, 8, 1-9. http://doi.org/10.4236/ib.2016.81001

Olowookere, J. K., \& Fasina, H. T (2013). Taxpayers' Education: A Key Strategy in Achieving Voluntary Compliance in Lagos State, Nigeria. European Journal of Business and Management, 5(10). 146-154. 
Organisation of Economic Cooperation and Development (2003). Educational attainment. Retrieved March 26, 2019, from https://stats.oecd.org/glossary/detail.asp?ID=742

Richardson, G. (2006). Determinants of tax evasion: A cross country investigation. Journal of International Accounting, Auditing and Taxation, 15(2), 150-169.

Saad, N. (2011). Tax non-compliance behavior: Taxpayers view. Social and Behavioral Sciences, 65, 344-351. http://doi.org/10.1016/j.sbspro.2012.11

Shaw, J. S. (n.d). Public choice theory. The Concise Encyclopedia of Economics. Retrieved October 17, 2019, from www.econlib.org/library/Enc1/PublicChoiceTheory.html

Shughart, W. F. (2019). Public choice. The Library of Economics and Liberty. Retrieved October 17, 2019, from https://www.econlib.org/library/Enc/PublicChoice.html

Torgler, B. (2012). Attitudes toward paying taxes in the USA: an empirical analysis the ethics of tax evasion. In McGee, R. W. W. (Ed.), The ethics of tax evasion: Perspectives in theory and practice. New York: Springer.

Ugbogbo, H. E., Akwemoh, M. O., \& Omoregie, C. B., (2013). The role and challenges of education in national development (the Nigeria experience). Journal of Educational and Social Research, 3(10), 25-30.

UNDP. (2018). Human Development Indices and Indicators: 2018 Statistical Update. Retrieved from hdr.undp.org/sites/all/themes/hdr_theme/country-notes/NGA.pdf

Vanguard. (2018, September 5). UNDP report says Nigeria's Human Development Index $\begin{array}{lllll}\text { rises by } & 2 & \text { points. } & \text { Retrieved }\end{array}$ https://www.vanguardngr.com/2018/09/undp-report-says-nigerias-human-development-index -rises-by-2-points/

Wadesango, N., \& Mwandambira, N. (2018). Evaluating the impact of tax knowledge on tax compliance among small medium enterprises in a developing country. Academy of Accounting and Financial Studies Journal, 22(6), 1-14.

Wong, R. M. K., \& Lo, A. W. Y. (2015). Can education improve tax compliance? Evidence from different forms of tax education. HKIBS Working Paper Series 074-1415. Retrieved from http://commons.ln.edu.hk/hkibswp/93

\section{Copyright Disclaimer}

Copyright for this article is retained by the author(s), with first publication rights granted to the journal.

This is an open-access article distributed under the terms and conditions of the Creative Commons Attribution license (http://creativecommons.org/licenses/by/4.0/) 